\title{
O Supremo Tribunal Federal e a lei Maria da Penha - uma lamentável decisão
}

\author{
Brazilian Supreme Court and the "Maria da Penha" law: \\ an unfortunate decision
}

Rômulo de Andrade Moreira ${ }^{1}$

Procurador de Justiça na Bahia romuloamoreira@uol.com.br

"Saimos da ditadura do masculino para a ditadura de um feminino estereotipado. Um feminino que nega tudo o que é feminino."

1 Procurador de Justiça na Bahia e Coordenador do Centro de Especialização e Aperfeiçoamento Funcional do Ministério Público da Bahia. Foi Assessor Especial da Procuradoria Geral de Justiça, Coordenador do Centro de Apoio Operacional das Promotorias Criminais e Procurador-Geral de Justiça Adjunto para Assuntos Jurídicos. Ex- Procurador da Fazenda Estadual. Professor de Direito Processual Penal da Universidade Salvador - UNIFACS, na graduação e na pós-graduação (Especialização em Direito Processual Penal e Penal e Direito Público). Pós-graduado, lato sensu, pela Universidade de Salamanca/Espanha (Direito Processual Penal). Especialista em Processo pela Universidade Salvador - UNIFACS (Curso então coordenado pelo Jurista J. J. Calmon de Passos). Membro da Association Internationale de Droit Penal, da Associação Brasileira de Professores de Ciências Penais e do Instituto Brasileiro de Direito Processual. Associado ao Instituto Brasileiro de Ciências Criminais - IBCCrim.Membro fundador do Instituto Baiano de Direito Processual Penal. Integrante, por quatro vezes, de bancas examinadoras de concurso público para ingresso na carreira do Ministério Público do Estado da Bahia. Professor convidado dos cursos de pós-graduação dos Cursos JusPodivm (BA), Praetorium (MG), IELF (SP) e do Centro de Aperfeiçoamento e Atualização Funcional do Ministério Público da Bahia. Autor das obras "Curso Temático de Direito Processual Penal" e "Comentários à Lei Maria da Penha" (este em coautoria com Issac Sabbá Guimarães), ambas publicadas pela Editora Juruá, 2010 (Curitiba); "A Prisão Processual, a Fiança, a Liberdade Provisória e as demais Medidas Cautelares - Comentários à Lei no. 12.403/11", "Juizados Especiais Criminais", "Comentários à Lei do Crime Organizado" e "Crítica à Teoria Geral do Processo", todos estes publicados pela Editora LexMagister, Porto Alegre/RS, além de coordenador do livro "Leituras Complementares de Direito Processual Penal”, publicado pela Editora JusPodivm, 2008. Participante em várias obras coletivas. Palestrante em diversos eventos realizados no Brasil.

2 Janaína Paschoal, "Mulher e Direito Penal", Coordenadores: Miguel Reale Júnior e Janaína Paschoal, Rio de Janeiro: Forense, 2007, p. 3. 
Resumo: O trabalho analisa duas decisões tomadas pelo Supremo Tribunal Federal na sessão do último dia 09 de fevereiro. A primeira, por maioria, julgou procedente a ADIn $n^{\circ} .4424$ quanto aos artigos 12, I, 16 e 41 da Lei $n^{\circ}$. 11.340/06. Na mesma sessão, por unanimidade, os Ministros acompanharam o voto do relator da ADC $n^{\circ}$. 19, Ministro Marco Aurélio, e declararam constitucionais os arts. $1^{\circ}$., 33 e 41 da lei. Discordando do entendimento da Suprema Corte, procuramos confrontar alguns dispositivos da Lei Maria da Penha com a Constituição Federal, concluindo que os seus arts. 17 e 41, além do art. 313, IV do Código de Processo Penal, não devem ser aplicados, pois incompatíveis com a Constituição Federal.

Palavras-Chave: Violência Doméstica - Crime de Menor Potencial Ofensivo - Juizados Especiais Criminais - Constituição Federal Princípio da Proporcionalidade - Princípio da Igualdade.

ABstRACT: The paper analyzes two decisions of the Supreme Court in the last session on February 09th. The first, by majority, upheld the ADIn $n^{\circ}$. 4424, concerning the articles 12, I, 16 and 41 of Law $n^{\circ}$. 11.340/06. In the same session, unanimously, the Ministers followed the rapporteur of the ADC $n^{\circ} 19$, Minister Marco Aurelio, and declared constitucional the articles $1^{\circ}$., 33 and 41 from the law. Disagreeing from the understanding of the Supreme Court, we confront, in this paper, some articles of Maria da Penha Law with the Federal Constitution, concluding that the articles from the referred law 17 and 41, besides the art. 313, IV of the Code of Criminal Procedure, should not be applied because they are incompatible with the Federal Constitution.

KEYWORDs: Domestic Violence - Crime of lower offensive potential - Special Criminal Courts - Federal Constitution - Proportionality's Principle Equality's Principle.

\section{I - INTRODUÇÃO}

O Plenário do Supremo Tribunal Federal julgou procedente, na sessão do último dia 09 de fevereiro, por maioria, a Ação Direta de Inconstitucionalidade (ADI 4424) ajuizada pela Procuradoria-Geral 
da República quanto aos artigos 12, inciso I; 16; e 41 da Lei Maria da Penha. Na mesma sessão, agora por unanimidade, os Ministros acompanharam o voto do relator da Ação Declaratória de Constitucionalidade (ADC) no 19, Ministro Marco Aurélio, e concluíram pela procedência do pedido a fim de declarar constitucionais os artigos 10 33 e 41, da Lei Maria da Penha. ${ }^{3}$ Ademais, a decisão do Supremo Tribunal Federal na Ação Direta de Inconstitucionalidade (ADI) 4424 produziu efeitos antes mesmo da publicação do acórdão. Com base nesse entendimento, o Ministro do STF Luís Roberto Barroso deferiu liminar em Reclamação (RCL 16031) para manter o curso de ação penal contra um morador de Osasco (SP), acusado de agredir a ex-companheira em ambiente doméstico. Ao analisar a liminar na RCL 4424, o Ministro Luís Roberto Barroso considerou presente a plausibilidade jurídica da tese defendida pelo MP-SP “de que proferida decisão em ADI, seu efeito vinculante produz-se antes da publicação, o que conduz à conclusão, em exame preambular, de que a decisão atacada afronta a autoridade decisória da Corte", disse o ministro-relator. Segundo Barroso, "o perigo na demora decorre da possibilidade de o decurso do tempo prejudicar a persecução criminal, atingindo-a com a prescrição". Diante disso, o ministro deferiu a liminar para suspender o efeito da decisão proferida pelo juízo da $4^{\text {a }}$ Vara Criminal da Comarca de Osasco que declarou extinta a punibilidade do autor pela renúncia da representação.

Assim, o ministro determinou que o juízo reclamado seja comunicado da decisão, de modo a viabilizar o andamento do processo, considerando a natureza pública incondicionada de eventual ação penal, nos termos do julgado na ADI 4424 pelo Supremo Tribunal Federal.

Sobre o assunto, além de vários artigos já publicados na internet, indicamos: "Comentários à Lei de Violência Doméstica e Familiar contr a Mulher", obra coletiva publicada pela Editora Lumen Juris (2008) e organizada por Adriana Ramos de Mello; "Violência Doméstica", de Rogério Sanches Cunha e Ronaldo Batista Pinto, São Paulo: Editora Revista dos Tribunais, 2007; "Violência Doméstica", de Stela Valéria Soares de Farias Cavalcanti, Salvador: Editora JusPodivm, 2007 e "Estudos sobre as novas leis de violência doméstica contra a mulher e de tóxicos”, obra coletiva coordenada por André Guilherme Tavares de Freitas, Rio de Janeiro: Editora Lumen Juris, 2007. 
Nada obstante o argumento de autoridade que representa um julgamento pelo Plenário do Supremo Tribunal Federal, ousamos discordar e afirmar, em alguns pontos, a inconstitucionalidade da Lei ${ }^{\circ}$. 11.340/2012.

Como se sabe, "configura violência doméstica e familiar contra a mulher qualquer ação ou omissão baseada no gênero que lhe cause morte, lesão, sofrimento físico, sexual ou psicológico e dano moral ou patrimonial." $\mathrm{A}$ violência pode ser praticada: a) "no âmbito da unidade doméstica, compreendida como o espaço de convívio permanente de pessoas, com ou sem vinculo familiar, inclusive as esporadicamente agregadas"; b) "no âmbito da família, compreendida como a comunidade formada por indivíduos que são ou se consideram aparentados, unidos por laços naturais, por afinidade ou por vontade expressa" ou c) "em qualquer relação intima de afeto, na qual o agressor conviva ou tenha convivido com a ofendida, independentemente de coabitação."

4 "O declinio primitivo e que deu azo ao presente conflito afirmou não se tratar de violência de gênero, uma vez que as envolvidas são do sexo feminino. Na esteira do vem decidindo o STJ, o sujeito passivo da violência doméstica, objeto da Lei 11.340/06 é a mulher, sendo certo que o sujeito ativo pode ser tanto o homem quanto a mulher, desde que fique caracterizado o vínculo de relação doméstica, familiar ou de afetividade, o que restou cabalmente demonstrado neste autos, de onde exsurge a hipótese contemplada no inciso II, do art. $5^{\circ}$, da Lei da regência. Ademais a condição peculiar da mulher (vitima) prevista no art. 4º, da Lei Especial, está perfeitamente delineada com ofim social a que se destina a legislação em comento. A Lei Maria da Penha é um exemplo de implementação para a tutela do gênero feminino, justificando-se pela situação de vulnerabilidade e hipossuficiência em que se encontram as mulheres vitimas da violência doméstica e familiar" (TJRJ 8a C. CC 2009.055.00401 - rel. Gilmar Augusto Teixeira - j.30.09.2009).

5 "Lesão corporal cometido por sogra à nora. I-Conflito suscitado no juízo criminal comum em face de Juizado de Violência Doméstica e Familiar Contra a Mulher da Comarca da Capital, para julgamento de delito praticado na vigência da Lei 11.340/06. II - O artigo 129, \$ $9^{\circ}$ do Código Penal é aplicável às hipóteses de violência doméstica, nas quais a lesão corporal é praticada contra pessoas que integram estrutura familiar, in casu sogra e nora, ligadas, portanto, por laços de afinidade, não importando se entre pessoas do mesmo sexo, amoldando-se os fatos, em consequência, ao disposto $5^{\circ}$ e 14 da Lei 11.340/06. Conflito Procedente" (TJRJ - 2a C. CC 2009.055.00320 - rel. Kátia Jangutta - j.03.09.2009).

6 O namoro é uma relação íntima de afeto sujeita à aplicação da Lei 11.340/06. Quando a agressão é praticada em decorrência dessa relação, o Ministério 
Ademais, compreende: a) "a violência física, entendida como qualquer conduta que ofenda sua integridade ou saúde corporal'; b) “a violência psicológica, entendida como qualquer conduta que lhe cause dano emocional e diminuição da auto-estima ou que the prejudique e perturbe o pleno desenvolvimento ou que vise degradar ou controlar suas açôes, comportamentos, crenças e decisóes, mediante ameaça, constrangimento, humilhação, manipulação, isolamento, vigilância constante, perseguição contumaz, insulto, chantagem, ridicularização, exploração e limitação do direito de ir e vir ou qualquer outro meio que lhe cause prejuizo à saúde psicológica e à

Público pode requerer medidas para proteger a vítima e seus familiares. $\mathrm{O}$ entendimento é da 6a. Turma do Superior Tribunal de Justiça e foi firmado no julgamento do pedido de Habeas Corpus de um agressor que tentava suspender a proibição de chegar a menos de 50 metros da ex-namorada e do filho dela. A restrição foi imposta pela Justiça do Rio Grande do Sul em ação proposta pelo Ministério Público com base na Lei Maria da Penha. A defesa do agressor alegou a inconstitucionalidade da lei por privilegiar a mulher em detrimento do homem, a ilegitimidade do Ministério Público e disse que não havia relação doméstica entre o casal, pois namoraram por pouco tempo, sem a intenção de constituir família. De acordo com o inquérito policial, a vítima trabalhava com o agressor e os dois namoraram por quatro anos. Após o término do relacionamento, o agressor passou a espalhar panfletos difamatórios contra a ex-namorada, pichou o muro de sua residência e é suspeito de ter provocado um incêndio na garagem da casa dela. Seguindo o voto da relatora no STJ, desembargadora

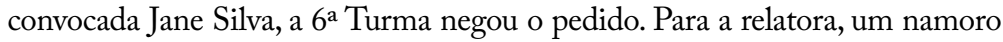
de quatro anos configura, para os efeitos da Lei Maria da Penha, relação doméstica ou de família, não simplesmente pela duração, mas porque o namoro é um relacionamento íntimo. A própria lei afasta a necessidade de coabitação para caracterizar a relação íntima de afeto. Assim, o Ministério Público tem legitimidade para propor medidas de proteção. A decisão ressalta ainda que declarar a constitucionalidade ou não da lei é atribuição do Supremo Tribunal

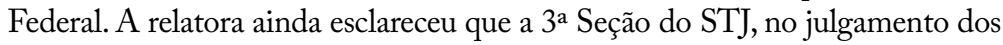
conflitos de competência 91.980 e 94.447 , não decidiu se a relação de namoro é ou não alcançada pela Lei Maria da Penha. O entendimento da Corte Superior naqueles casos específicos foi de que a violência praticada contra a mulher não decorria da relação de namoro. De acordo com Jane Silva, quando há a comprovação de que a violência praticada contra a mulher, vítima de violência doméstica por sua vulnerabilidade e hipossuficiência, decorre do namoro e que esta relação, independentemente de coabitação, pode ser considerada íntima, aplica-se a Lei Maria da Penha. (HC 92.875). 
autodeterminação"; c) "a violência sexual, entendida como qualquer conduta que a constranja a presenciar, a manter ou a participar de relação sexual não desejada, mediante intimidação, ameaça, coação ou uso da força; que a induza a comercializar ou a utilizar, de qualquer modo, a sua sexualidade, que a impeça de usar qualquer método contraceptivo ou que a force ao matrimônio, à gravidez, ao aborto ou à prostituição, mediante coação, chantagem, suborno ou manipulação; ou que limite ou anule o exercício de seus direitos sexuais e reprodutivos"; d) "a violência patrimonial, entendida como qualquer conduta que configure retenção, subtração, destruição parcial ou total de seus objetos, instrumentos de trabalho, documentos pessoais, bens, valores e direitos ou recursos econômicos, incluindo os destinados a satisfazer suas necessidades" e e) "a violência moral, entendida como qualquer conduta que configure calúnia, difamação ou injúria."

É importante ressaltar que a lei não contém nenhum novo tipo penal, apenas dá um tratamento penal e processual distinto para as infrações penais já elencadas em nossa (vasta e exagerada) legislação. De toda maneira, entendemos extremamente perigosa a utilização, em um texto legal de natureza penal e processual penal (e gravoso para o indivíduo), de termos tais como "diminuição da auto-estima", "esporadicamente agregadas", "individuos que são ou se consideram aparentados", "em qualquer relação intima de afeto", etc., etc.

Observa-se, porém, que uma agressão de ex-namorado contra antiga parceira não configura violência doméstica. Com esse entendimento, a Terceira Seção do Superior Tribunal de Justiça, por maioria, declarou competente o juízo de direito do Juizado Especial Criminal de Conselheiro Lafaiete, em Minas Gerais, para julgar e processar ação contra agressor da ex-namorada. No caso, o homem encontrou a ex-namorada na companhia do atual parceiro e praticou a agressão. Ele jogou um copo de cerveja no rosto dela, deu-lhe um tapa e a ameaçou. O Ministério Público entendeu ser caso de violência doméstica e, por isso, considerou que deveria ser julgado pela Justiça comum. Acatando esse parecer, o juízo de Direito do Juizado Especial Criminal de Conselheiro Lafaiete encaminhou os autos para a $1^{\text {a }}$ Vara Criminal da cidade. Porém, a Vara Criminal levantou o conflito de competência por entender que não se tratava de violência doméstica e, por essa razão, a questão deveria ser julgada pelo Juizado Especial. Em 
sua decisão, o relator, ministro Nilson Naves, destacou que a Lei Maria da Penha não abrange as conseqüências de um namoro acabado. Por isso, a competência é do Juizado Especial Criminal. Acompanharam o relator os ministros Felix Fischer, Laurita Vaz, Arnaldo Esteves Lima, Maria Thereza de Assis Moura, Jorge Mussi e Og Fernandes. O ministro Napoleão Nunes Maia Filho divergiu do relator e foi acompanhado pela desembargadora convocada Jane Silva. Segundo ela, o namoro configura, para os efeitos da Lei Maria da Penha, relação doméstica ou familiar, já que trata de uma relação de afeto." (Processos: CC 91980 e CC 94447).

Segundo o seu art. $6^{\circ}$., a violência doméstica e familiar contra a mulher constitui uma das formas de violação dos direitos humanos; logo, é possível que a apuração do crime daí decorrente seja da atribuição da Polícia Federal, na forma do art. $1^{\circ}$., caput e inciso III, da Lei no. 10.446/02; ainda em tese, também é possível que a competência para o processo e julgamento seja da Justiça Comum Federal, ex vi do art. 109, V-A, c/c o $§ 5^{\circ}$., da Constituição Federal, desde que se inicie, via Procurador-Geral da República, e seja julgado procedente o Incidente de Deslocamento de Competência junto ao Superior Tribunal de Justiça). Esta conclusão decorre das normas referidas, bem como em razão do Brasil ser subscritor da Convenção sobre a eliminação de todas as formas de violência contra a mulher ${ }^{7}$ e da Convenção interamericana para prevenir, punir e erradicar a violência contra a mulher.

Não pretendemos ferir suscetibilidades ou idiossincrasias, apenas manifestar o nosso entendimento sobre uma norma jurídica que entendemos ferir a Constituição Federal. Como diz Paulo Freire, "só, na verdade, quem pensa certo, mesmo que, às vezes, pense errado, é quem pode ensinar a pensar certo. E uma das condições necessárias a pensar certo é não estarmos demasiado certos de nossas certezas. Por isso é que o pensar certo, ao lado sempre da pureza e necessariamente distante do puritanismo, rigorosa-

7 Aprovada pela Organização das Nações Unidas em 1979 e ratificada pelo Brasil em 1984.

8 Firmada em 1994 na cidade brasileira de Belém do Pará, adotada pela Assembléia Geral da Organização dos Estados Americanos em 6 de junho de 1994 e ratificada pelo Brasil em 27 de novembro de 1995. 
mente ético e gerador de boniteza, me parece inconciliável com a desvergonha da arrogância de quem se acha cheia ou cheio de si mesmo."

Estamos de acordo com a tutela penal diferençada para hipossuficientes (inclusive pelo desvalor da ação ${ }^{10}$ ), mas sem máculas à Constituição Federal e aos princípios dela decorrentes e inafastáveis.

9 Pedagogia da Autonomia, São Paulo: Paz e Terra, 35a . ed., 2007, p. 28.

${ }_{10}$ Como se sabe, a antijuridicidade de um comportamento é composta pelo chamado desvalor da ação e pelo desvalor do resultado; o primeiro, segundo Cezar Roberto Bitencourt, é a "forma ou modalidade de concretizar a ofensa", enquanto que o segundo é "a lesão ou exposição a perigo do bem ou interesse juridicamente protegido." Este mesmo autor, citando agora Jescheck, ensina que modernamente a "antijuridicidade do fato não se esgota na desaprovação do resultado, mas que 'a forma de produção' desse resultado, juridicamente desaprovado, também deve ser incluído no juizo de desvalor." (Teoria Geral do Delito, São Paulo: Editora Revista dos Tribunais, p. 121/124). Segundo Luiz Flávio Gomes, deve-se a Welzel "o enfoque do delito como desvalor da ação (negação de um valor pela ação) mais desvalor do resultado. (...) O delito não é fruto exclusivamente do desvalor do resultado, senão sobretudo (na visão de Welzel) do desvalor da ação, que, no seu sistema, goza de primazia. O desvalor da ação, de qualquer modo, passa a constituir requisito obrigatório de todo delito." (Estudos de Direito Penal e Processo Penal, São Paulo: Editora Revista dos Tribunais, 1999, pp. 220/221). Assim, é inegável que o estudo da antijuridicidade leva à conclusão de que esta se perfaz não apenas com a valoração do resultado como também (e tanto quanto) com o juízo de valor a respeito da ação (ou omissão). Munõz Conde, na sua Teoria Geral do Delito, explica bem esta dicotomia e a imprescindibilidade da conjunção entre estes dois elementos: "Nem toda lesão ou colocação em perigo de um bem jurídico (desvalor do resultado) é antijurídica, mas apenas aquela que deriva de uma ação desaprovada pelo ordenamento jurídico (desvalor da ação)." Em vista dessa percepção, diz o mesmo autor que o Direito Penal "não sanciona toda lesão ou colocação em perigo de um bem jurídico, mas só aquelas que são conseqüências de açôes especialmente intoleráveis." E continua o mestre espanhol: "Ambos os conceitos, desvalor da ação e desvalor do resultado, são igualmente importantes na configuração da antijuridicidade, de vez que estão perfeitamente entrelaçados e são inimagináveis separados (...), contribuindo ambos, no mesmo nivel, para constituir a antijuridicidade de um comportamento.". (...) "O que sucede é que, por razóes de politica criminal, o legislador na hora de configurar os tipos delitivos pode destacar ou fazer recair acento em um ou em outro tipo de desvalor." (Teoria Geral do Delito, Porto Alegre: Sergio Antonio Fabris Editor, 1988, tradução de Juarez Tavares e Luiz Régis Prado, p. 88/89). 
Neste ponto, concordamos com Naele Ochoa Piazzeta, quando afirma que "corretas, certas e justas modificações nos diplomas legais devem ser buscadas no sentido de se ver o verdadeiro princípio da igualdade entre os gêneros, marco de uma sociedade que persevera na luta pela isonomia entre os seres humanos, plenamente alcançado." ${ }^{11}$

Como afirma Willis Santiago Guerra Filho, "princípios como o da isonomia e proporcionalidade são engrenagens essenciais do mecanismo político-constitucional de acomodação dos diversos interesses em jogo, em dada sociedade, sendo, portanto, indispensáveis para garantir a preservação de direitos fundamentais, donde podermos inclui-los na categoria, equiparável, das 'garantias fundamentais." 12

\section{II - A RETRATAÇÃO DA REPRESENTAÇÃO}

Inicialmente analisaremos o art. 16 da referida lei que tem a seguinte redação: "Nas ações penais públicas condicionadas à representação da ofendida de que trata esta Lei, só será admitida a renúncia à representação perante o juiz, em audiencia especialmente designada com tal finalidade, antes do recebimento da denúncia e ouvido o Ministério Público."

Desde logo, atentemos para a impropriedade técnica do termo "renúncia", pois se o direito de representação já foi exercido (tanto que foi oferecida a denúncia), obviamente não há falar-se em renúncia; certamente o legislador quis referir-se à retratação da representação, o que é perfeitamente possível, mesmo após o oferecimento daquela condição específica de procedibilidade da ação penal.

Sabe-se, no entanto, que o art. 25 do Código de Processo Penal só permite a retratação da representação até o oferecimento da denúncia; no caso desta lei, porém, a solução do legislador foi outra, permitindo-se a retratação mesmo após o oferecimento da peça acusatória. O limite agora (e quando se tratar de crime relacionado à violência doméstica e familiar contra a mulher) é a decisão do Juiz recebendo a denúncia.

11 O Princípio da Igualdade no Direito Penal Brasileiro - Uma Abordagem de Gênero, Porto Alegre: Livraria do Advogado Editora, 2001, p. 174.

12 Introdução ao Direito Processual Constitucional, Porto Alegre: Síntese, 1999, p. 46. 
Portanto, diferentemente da regra estabelecida pelo art. 25 do Código de Processo Penal, a retratação da representação pode ser manifestada após o oferecimento da denúncia, desde que antes da decisão acerca de sua admissibilidade. Neste ponto, mais duas observações: em primeiro lugar a lei foi mais branda com os autores de crimes praticados naquelas circunstâncias, o que demonstra de certa forma uma incoerência do legislador. Ora, se se queria reprimir com mais ênfase este tipo de violência, por que "elastecer" o prazo para a retratação da representação? Evidentemente que é mais benéfica para o autor do crime a possibilidade de retratação em tempo maior que aquele previsto pelo art. 25, CPP.

Tratando-se de norma processual penal material, e sendo mais benéfica, deve retroagir para atingir processos relativos aos crimes praticados anteriormente à vigência da lei (data da ação ou omissão - arts. $2^{\circ}$. e $4^{\circ}$. do Código Penal). ${ }^{13}$

Uma segunda observação é a exigência legal que esta retratação somente possa ser feita "perante o juiz, em audiência especialmente designada com tal finalidade, (...) ouvido o Ministério Público." Aqui, a intenção do legislador foi revestir a retratação de toda a formalidade própria de uma audiência realizada no Juízo Criminal, presentes o Juiz de Direito e o Ministério Público. Neste aspecto, sendo mais gravosa a norma processual penal material, sua aplicação deve se restringir aos fatos ocorridos posteriormente, ou seja, para os crimes praticados após a vigência da lei.

De toda maneira, ressaltamos que se esta retratação deve ser necessariamente formal (e formalizada), o mesmo não ocorre com a representação que, como sabemos, dispensa maiores formalidades (sendo este um entendimento já bastante tranquilo dos nossos tribunais e mesmo da Suprema Corte). O prazo para o oferecimento da representação (bem como o dies a quo) continua sendo o mesmo (art. 38, $\mathrm{CPP})$. Ademais, é perfeitamente válida a representação feita perante a autoridade policial, pois assim permite o art. 39 do CPP.

13 Sobre a sucessão das leis processuais no tempo, conferir o nosso "Juizados Especiais Criminais”, Salvador: JusPodivm, 2007, págs. 101 a 107. 
Como se sabe, a representação é uma condição processual relativa a determinados delitos, sem a qual a respectiva ação penal, nada obstante ser pública, não pode ser iniciada pelo órgão ministerial; é uma manifestação de vontade externada pelo ofendido (ou por quem legalmente o represente) no sentido de que se proceda à persecutio criminis. De regra, esta representação "consiste em declaração escrita ou oral, dirigida à autoridade policial, ou ao órgão do Ministério Público, ou ao Juiz", como afirmava Borges da Rosa. ${ }^{14}$ Porém, a doutrina e a jurisprudência pátrias trataram de amenizar este rigor outrora exigido, a fim de que pudessem ser dados ao instituto da representação traços mais informais e, conseqüentemente, mais justos e consentâneos com a realidade.

Assim é que hodiernamente "a representação, quanto à formalidade, é figura processual que se reveste da maior simplicidade. Inocorre, em relação à mesma qualquer rigor formal" e esta "dispensa do requisito das formalidades advém da circunstância de que a representação é instituída no interesse da vitima e não do acusado, dai a forma mais livre possível na sua elaboração."15

Neste sentido a jurisprudência é pacífica:

“SUPERIOR TRIBUNAL DE JUSTIÇA - HABEAS CORPUS No. 20.401 - RJ (2002/0004648-6) (DJU 05.08.02, SEÇÃO 1, P. 414, J. 17.06.02). RELATOR: MINISTRO FERNANDO GONÇALVES. EMENTA: PROCESSUAL PENAL. HABEAS CORPUS. PERDA DO OBJETO. CRIME CONTRA OS COSTUMES. ATENTADO VIOLENTO AO PUDOR. REPRESENTAÇÃO. FORMA SACRAMENTAL. INEXIGIBILIDADE. 1 - Resta prejudicado o habeas corpus, por falta de objeto, quando o motivo do constrangimento não mais existe. 2 - Nos crimes de ação pública, condicionada à representação, esta independe de forma sacramental, bastando que fique demonstrada, como na espécie, a inequivoca intenção da vitima elou seu representante legal, nesta extensão, em processar o ofensor. Decadência afastada. 3 - Ordem conbecida em parte e, nesta extensão, denegada."

14 Processo Penal Brasileiro, Vol. I, p. 169.

15 Ação Penal nos Crimes Contra os Costumes, de Geraldo Batista de Siqueira, p. 24. 
Aliás, este é o entendimento pacífico do Supremo Tribunal Federal (neste sentido conferir RT 731/522; JSTF 233/390; RT 680/429, etc). No julgamento do Habeas Corpus no. 88843, por unanimidade, os Ministros da Primeira Turma do Supremo Tribunal Federal, apesar de concederem a ordem de ofício (para afastar qualquer impedimento contra a progressão do regime prisional em favor de um condenado por atentado violento ao pudor com violência presumida), negaram, no entanto, o pedido formulado pela defesa por entender " que, de acordo com diversos precedentes da Corte, o entendimento firmado no STF é de que não se deve exigir a observância rígida das regras quanto à representação, principalmente quando se trata de crimes dessa natureza", segundo o relator, Ministro Marco Aurélio. Para a Defensoria Pública paulista, que impetrou a ação no Supremo em favor do condenado, a decisão do Superior Tribunal de Justiça, que negou pedido idêntico feito àquela corte, estaria equivocada, uma vez que seria necessário haver uma representação formal contra o réu, para que ele fosse processado. E que a representação que houve, no caso, foi feita pela vítima, uma menor de idade. O depoimento da vítima, menor de idade, manifestando a intenção de perseguir o acusado em juízo, foi usado para suprir a representação, disse o defensor público. Como a vítima é menor de idade, tal depoimento não é valido, não supre a representação, afirmou ainda a defensoria, para quem "aceitar essa tese é burlar o devido processo legal'. Fonte: STF.

Pergunta-se: deve o representante do Ministério Público, antes de oferecer a denúncia, pugnar ao Juiz pela realização daquela audiência? Entendemos que não, pois a audiência prevista neste artigo deve ser realizada apenas se a vítima (ou seu representante legal ou sucessores ou mesmo o curador especial - art. 33 do Código de Processo Penal) manifestar algum interesse em se retratar da representação. Não vemos necessidade de, a priori, o órgão do Ministério Público requerer a designação da audiência. Ora, se a vítima representou (seja formal ou informalmente), satisfeita está a condição específica de procedibilidade para a ação penal. O requerimento para a realização desta audiência (ou a sua designação ex officio pelo Juiz de Direito) fica "até parecendo" que se deseja a retratação a todo custo.

Observa-se, outrossim, que a retratação deve ser um ato espontâneo da vítima (ou de quem legitimado legalmente), não sendo 
necessário que ela seja levada a se retratar por força da realização de uma audiência judicial.

Exatamente neste sentido, o Superior Tribunal de Justiça decidiu que "a vítima de violência doméstica não pode ser constrangida a ratificar perante o juízo, na presença de seu agressor, a representação para que tenha seguimento a ação penal. Com esse entendimento, a Quinta Turma do Superior Tribunal de Justiça concedeu mandado de segurança ao Ministério Público do Mato Grosso do Sul para que a audiência prevista no artigo 16 da Lei Maria da Penha só ocorra quando a vítima manifeste, antecipada, espontânea e livremente, o interesse de se retratar. A decisão é unânime. A Lei 11.340/06, conhecida por Maria da Penha, criou mecanismos de proteção contra a violência doméstica e familiar sofrida pelas mulheres. Entre as medidas, está a previsão de que a ação penal por lesão corporal leve é pública - isto é, deve ser tocada pelo MP-, mas condicionada à representação da vítima. $O$ STJ já pacificou o entendimento de que essa representação não exige qualquer formalidade, bastando a manifestação perante autoridade policial para configurá-la. Para o Tribunal de Justiça sul-matogrossense, a designação dessa audiência seria ato judicial de mero impulso processual, não configurando ilegalidade ou arbitrariedade caso realizada espontaneamente pelo juiz. Mas o desembargador convocado Adilson Macabu divergiu do tribunal local. Para - relator, a audiência prevista no dispositivo não deve ser realizada de ofício, como condição da abertura da ação penal, sob pena de constrangimento ilegal à mulher vitima de violência doméstica e familiar. Isso "configuraria ato de 'ratificação' da representação, inadmissivel na espécie", asseverou. "Como se observa da simples leitura do dispositivo legal, a audiência a que refere o artigo somente se realizará caso a ofendida expresse previamente sua vontade de se retratar da representação ofertada em desfavor do agressor", acrescentou 0 relator. "Assim, não há falar em obrigatoriedade da realização de tal audiência, por iniciativa do juízo, sob o argumento de tornar certa a manifestação de vontade da vítima, inclusive no sentido de 'não se retratar' da representação já realizada", completou. Em seu voto, o desembargador indicou precedentes tanto da Quinta quanto da Sexta Turma nesse mesmo sentido." (Fonte: Coordenadoria de Editoria e Imprensa do Superior Tribunal de Justiça).

Também no Supremo Tribunal Federal decidiu-se que " a audiência prevista no referido artigo não é obrigatória para o recebimento da denúncia, como sustentava a defesa. Ela é facultativa e deve ser provocada pela vítima, 
caso deseje, antes de recebida a denúncia, o que não ocorreu no caso em questão." (Habeas Corpus 109176, Relator Ministro Ricardo Lewandowski).

\section{III - A APLICAÇÃO DA PENA DE PRESTAÇÃO PECUNIÁRIA}

Em seguida, dispõe o art. 17 ser "vedada a aplicação, nos casos de violência doméstica e familiar contra a mulher, de penas de cesta básica ou outras de prestação pecuniária, bem como a substituição de pena que implique o pagamento isolado de multa."

A princípio, tendo em vista o disposto no art. 41 da mesma lei (que adiante iremos comentar), a proibição da aplicação da pena de prestação pecuniária (ou multa) é dirigida ao Juiz de Direito, no momento em que irá proferir a sentença condenatória. Sim, pois se se admitir a impossibilidade da transação penal (art. 41), evidentemente que o dispositivo comentado refere-se, tão-somente, à sentença condenatória.

A pena alternativa de prestação pecuniária está prevista no art. 43, I do Código Penal e consiste no pagamento em dinheiro à vítima, a seus dependentes ou a entidade pública ou privada com destinação social, de importância fixada pelo juiz, não inferior a 1 (um) salário mínimo nem superior a 360 (trezentos e sessenta) salários mínimos. O valor pago será deduzido do montante de eventual condenação em ação de reparação civil, se coincidentes os beneficiários. Se houver aceitação do beneficiário, a prestação pecuniária pode consistir em prestação de outra natureza. ${ }^{16}$

Restou clara a intenção do legislador de evitar a barganha, a "troca" de uma cesta básica ou dinheiro ou multa pela agressão praticada contra a mulher naquelas circunstâncias já referidas no início. Interessante é a afirmação de Janaína Paschoal para quem, "tão bumilhante como buscar a punição de seu agressor e vế-lo sair vitorioso doando

${ }^{16}$ Entendemos que a expressão genérica "prestação de outra natureza" fere o princípio da legalidade. Cezar Roberto Bitencourt afirma que "essa falta de garantia e certeza sobre a natureza, espécie ou quantidade da 'prestação de outra natureza 'caracteriza a mais flagrante inconstitucionalidade!", exatamente por serem inadmissíveis, "em termos de sanções criminais", "expressões vagas, equivocas e ambiguas". 
uma única cesta básica, muita vez comprada pela própria vítima, é ver o Estado desconsiderar a sua vontade." 17

Apesar de ser coerente com a finalidade da lei, não cremos que tal disposição possa se sustentar frente à Constituição Federal, principalmente à luz dos princípios da proporcionalidade e da igualdade. Atentese, com Luiz Flávio Gomes, que "o princípio da proporcionalidade tem base constitucional (é extraído da conjugação de várias normas: arts. $1^{\circ}$., III, $3^{\circ}$., I, 5०., caput, II, XXXV, LIV, etc.) e complementa o princípio da legalidade." 18

Igualmente, "el principio de proporcionalidad que, como ya indicado, surgió en el Derecho de policia para pasar a impregnar posteriormente todo el Derecho público, ha de observarse también en el Derecho Penal."19

Por que proibir a aplicação de uma pena alternativa à pena privativa de liberdade em razão do sujeito passivo de um crime? A exclusão deve ser prevista em razão da gravidade do delito, não em razão da vítima ser mulher em situação de violência doméstica e familiar. $\mathrm{O}$ que justifica, à luz da Constituição Federal, a adoção de regime mais gravoso para determinados crimes é a própria gravidade do delito (aferida pela pena abstratamente cominada ou pelo bem jurídico tutelado, o que não é o caso, mesmo porque a lei não tipifica nenhuma conduta penalmente relevante).

A propósito, observamos, mutatis mutandis, que o art. $61 \mathrm{da}$ Lei $n^{\circ}$. 9.099/95 foi modificado exatamente para retirar aquela ressalva quanto ao procedimento especial (que ensejava a exclusão do crime como sendo de menor potencial ofensivo). A doutrina nunca entendeu muito bem o porquê da ressalva, pois o conceito de infração penal de menor potencial ofensivo deveria levar em conta apenas a pena máxima abstratamente cominada, sendo o tipo de procedimento absolutamente indiferente para aquele fim. Tal entendimento acabou prevalecendo com a promulgação da Lei no $.11 .313 / 06$ que alterou a redação do art. 61 da Lei no. 9.099/95.

17 Obra citada, p. 3.

18 Penas e Medidas Alternativas à Prisão, São Paulo: Editora Revista dos Tribunais, 1999, p. 66.

19 Nicolas Gonzalez-Cuellar Serrano, "Proporcionalidad y Derechos Fundamentales en el Proceso Penal”, Madri: Editorial Colex, 1990, p. 29. 
Note-se que a Constituição Federal, razoável e proporcionalmente, estabelece regimes penal e processual mais gravosos para autores dos chamados crimes hediondos, a tortura, o tráfico ilícito de drogas, o terrorismo, o racismo e a ação de grupos armados, civis ou militares, contra a ordem constitucional e o Estado Democrático; ao passo que permite medidas despenalizadoras quando se trata de infração penal de menor potencial ofensivo (cfr. arts. $5^{\circ}$., XLII, XLII e XLIV e 98, I, ambos da Constituição Federal).

Como, então, tratar diferentemente autores de crimes cuja pena máxima aplicada não foi superior a quatro anos, se atendidos os demais requisitos autorizadores da substituição (art. 44 do Código Penal)? Assim, acusados por crimes como furto, receptação, estelionato, apropriação indébita, peculato, concussão, etc., podem ser beneficiados pela substituição da pena privativa de liberdade por prestação pecuniária ou multa. Já um condenado por uma injúria ou uma ameaça (pena máxima de seis meses), estará impedido de ser beneficiado pela substituição, caso tenha praticado aqueles delitos contra uma mulher, em situação de violência doméstica e familiar.

Convenhamos tratar-se de um verdadeiro despautério; a violação aos referidos princípios constitucionais salta aos olhos!

Na lição de Sebástian Melo, "sendo o Direito Penal um instrumento de realização de Direitos Fundamentais, não pode prescindir do princípio da proporcionalidade para realização de seus fins. Esse princípio, mencionado com destaque pelos constitucionalistas, remonta a Aristóteles, que relaciona justiça com proporcionalidade, na medida em que assevera ser o justo uma das espécies do gênero proporcional. Seu conceito de proporcionalidade repudia tanto o excesso quanto a carência. A justiça proporcional, em Ética e Nicômaco é uma espécie de igualdade proporcional, em que cada um deve receber de forma proporcional ao seu mérito. Desta forma, para Aristóteles, a regra será justa quando seguir essa proporção. Nas palavras do filósofo grego em questão, a sua igualdade proporcional representa uma 'conjunção do primeiro termo de uma proporção com o terceiro, e do segundo com o quarto, e o justo nesta acepção é o meio-termo entre dois extremos desproporcionais, já que o proporcional é um meio termo, e o justo é o proporcional." ${ }^{20}$

20 "O Princípio da Proporcionalidade no Direito Penal", texto inserto na obra Princípios Penais Constitucionais, Salvador: Editora JusPodivm, 2007, p. 203. 
Ao comentarmos adiante o art. 41, aprofundaremos esta questão à luz dos referidos princípios constitucionais. Mas, desde logo, reafirmamos, com Humberto Ávila, que a igualdade (que ele denomina de postulado) "estrutura a aplicação do Direito quando há relação entre dois sujeitos em função de elementos (critério de diferenciação e finalidade da distinção) e da relação entre eles (congruência do critério em razão do fim)." Para ele, a proporcionalidade (que também seria um postulado) "aplica-se nos casos em que exista uma relação de causalidade entre um meio e um fim concretamente perceptível. A exigência de realização de vários fins, todos constitucionalmente legitimados, implica a adoção de medidas adequadas, necessárias e proporcionais em sentido estrito." ${ }^{1}$

\section{IV - AS MEDIDAS PROTETIVAS DE URGÊNCIA}

Quanto às medidas protetivas de urgência, assim chamadas pela lei, "poderão ser concedidas pelo juiz, a requerimento do Ministério Público ou a pedido da ofendida (art. 19), não havendo necessidade, no último caso, de ser o pedido subscrito por advogado ${ }^{22}$, e "independentemente de audiência das partes e de manifestação do Ministério Público."

Algumas destas medidas são salutares, seja do ponto de vista de proteção da mulher, seja sob o aspecto "descarcerizador" que elas encerram. Em outras palavras: é muito melhor que se aplique uma medida cautelar não privativa de liberdade do que se decrete uma prisão preventiva ou temporária (adiante trataremos do novo inciso acrescentado ao art. 313 do Código de Processo Penal). Exemplo poderíamos citar o art. 294 do Código de Trânsito Brasileiro (Lei no ${ }^{\circ}$ 9.503/97) que prevê, como medida cautelar e "havendo necessidade

${ }^{21}$ Teoria dos Princípios, São Paulo: Malheiros, 4ª ed., 2004, p. 131.

$22 \mathrm{O}$ art. 27, porém, exige que "em todos os atos processuais, civeis e criminais, a mulher em situação de violência doméstica e familiar deverá estar acompanhada de advogado, ressalvado o previsto no art. 19 desta Lei”, bem como ser "garantido a toda mulher em situação de violência doméstica e familiar o acesso aos serviços de Defensoria Pública ou de Assistência Judiciária Gratuita, nos termos da lei, em sede policial e judicial, mediante atendimento especifico e bumanizado." (art. 28). 
para garantia da ordem pública", a possibilidade de decretação " $d a$ suspensão da permissão ou da habilitação para dirigir veículo automotor, ou a proibição de sua obtenção", cabendo recurso em sentido estrito, sem efeito suspensivo, da decisão que decretar ou deixar de decretá-la (parágrafo único).

Como afirma Rogério Schietti Machado Cruz, "se a pena privativa de liberdade, como zênite e fim último do processo penal, é um mito que desmorona paulatinamente, nada mais racional do que também se restringir o uso de medidas homólogas (não deveriam ser) à prisão- pena, antes da sentença condenatória definitiva. É dizer, se a privação da liberdade como pena somente deve ser aplicada aos casos mais graves, em que não se mostra possivel e igualmente funcional outra forma menos aflitiva e agressiva, a privação da liberdade como medida cautelar também somente há de ser utilizada quando nenhuma outra medida menos gravosa puder alcançar o mesmo objetivo preventivo." ${ }^{23}$

A previsão de tais medidas protetivas (ao menos em relação a algumas delas) encontra respaldo na Resolução 45-110 da Assembléia Geral das Nações Unidas - Regras Mínimas da ONU para a Elaboração de Medidas Não-Privativas de Liberdade (Regras de Tóquio, editadas nos anos 90). Estas regras "enunciam um conjunto de princípios básicos para promover o emprego de medidas não-privativas de liberdade, assim como garantias minimas para as pessoas submetidas a medidas substitutivas da prisão." ${ }^{24}$

Por terem a natureza jurídica de medidas cautelares, devem observar, para a sua decretação, a presença do fumus commissi delicti e do periculum in mora.

Sem tais pressupostos, ilegítima será a imposição de tais medidas. Devemos atentar, porém, para a lição de Calmon de Passos, segundo a qual "o processo cautelar é processo de procedimento contencioso, vale dizer, no qual o princípio da bilateralidade deve ser atendido, sob pena de nulidade. A lei tolera a concessão inaudita altera

23 Prisão Cautelar - Dramas, Princípios e Alternativas, Rio de Janeiro: Lumen Juris, 2006, p. 132.

${ }^{24}$ Leonardo Sica, "Direito Penal de Emergência e Alternativas à Prisão", São Paulo: Editora Revista dos Tribunais, 2002, p. 123. 
pars de medida cautelar, nos casos estritos que menciona (art. 804), mas impóe, inclusive para que subsista a medida liminarmente concedida, efetive-se a citação do réu e se lhe enseje a oportunidade de se defender (arts. 802, II e 811, II)." ${ }^{25}$

Como, em tese, é possível a decretação da prisão preventiva em caso de descumprimento injustificado da medida protetiva (adiante comentaremos o art. 313, IV do Código de Processo Penal), entendemos ser perfeitamente cabível a utilização do habeas corpus para combater uma decisão que a aplicou. Como se sabe, o habeas corpus deve ser também conhecido e concedido sempre que alguém sofrer ou se achar ameaçado de sofrer violência ou coação em sua liberdade de locomoção, por ilegalidade ou abuso de poder.

Logo, se a medida protetiva foi abusiva (não necessária), cabível a utilização do babeas corpus que visa a tutelar a liberdade física, a liberdade de locomoção do homem: ius manendi, ambulandi, eundi ultro citroque. Como já ensinava Pontes de Miranda, em obra clássica sobre a matéria, é uma ação preponderantemente mandamental dirigida "contra quem viola ou ameaça violar a liberdade de ir, ficar e vir." 26 (Grifo nosso).

Para Celso Ribeiro Bastos "o habeas corpus é inegavelmente a mais destacada entre as medidas destinadas a garantir a liberdade pessoal. Protege esta no que ela tem de preliminar ao exercício de todos os demais direitos e liberdades. Defende-a na sua manifestação física, isto é, no direito de o indivíduo não poder sofrer constrição na sua liberdade de se locomover em razão de violência ou coação ilegal." ${ }^{7}$

Aliás, desde a Reforma Constitucional de 1926 que o habeas corpus, no Brasil, é ação destinada à tutela da liberdade de locomoção, ao direito de ir, vir e ficar.

Nada obstante tais considerações, foi impetrado e concedido um Mandado de Segurança para afastar decisão que aplicou medida

25 Comentários ao Código de Processo Civil, Vol. X, Tomo I, São Paulo: Editora Revista dos Tribunais, 1984, p. 139.

26 História e Prática do Habeas Corpus, Vol. I, Campinas: Bookseller, 1999, p. 39.

27 Comentários à Constituição do Brasil, Vol. II, São Paulo: Saraiva, 1989, p. 312. 
protetiva de urgência: "Inexiste dúvida quanto ao acerto da aplicação das medidas protetivas aplicadas pela autoridade impetrada em favor da ofendida, restringindo direitos do impetrante, porque previstas na denominada Lei 'Maria da Penha', o que afasta a alegação de violação a direito líquido e certo ou mesmo ocorrência de abuso de poder. Não se pode olvidar contudo, a especialíssima situação do impetrante, que tem o dever de cuidar de sua idosa mãe, atualmente com 85 anos de idade, até por imposição da Lei $n^{\circ}$ 10.741/2003 - Estatuto do Idoso - o que só será possível se o fizer pessoalmente, isto é, comparecendo à residência dela, não obstante situada no mesmo terreno da residência da ofendida, razão porque se concedeu parcialmente 0 pedido liminar apenas para possibilitar ao impetrante frequentar a casa da mãe e continuar a prestar os cuidados variados de que ela necessita, mas sem qualquer forma de contato com a ofendida, única forma possivel de conciliar a incidência dos diplomas legais aplicáveis à espécie. Concessão parcial, confirmando-se a liminar." (TJRJ - 3a C. - MS 2009.078.00019 - rel. Valmir de Oliveira Silva - j. 09.06.2009).

A propósito, pela primeira vez, o Superior Tribunal de Justiça admitiu a aplicação de medidas protetivas da Lei Maria da Penha (Lei 11.340/2006) em Ação Cível, sem existência de inquérito policial ou processo penal contra o suposto agressor.

A decisão é da $4^{\mathrm{a}}$ Turma. Para o relator do caso, Ministro Luis Felipe Salomão, a agregação de caráter cível às medidas protetivas à mulher previstas na Lei Maria da Penha amplia consideravelmente a proteção das vítimas de violência doméstica, uma vez que essas medidas assumem eficácia preventiva. "Parece claro que o intento de prevenção da violência doméstica contra a mulher pode ser perseguido com medidas judiciais de natureza não criminal, mesmo porque a resposta penal estatal só é desencadeada depois que, concretamente, o ilícito penal é cometido, muitas vezes com consequências irreversíveis, como no caso de homicídio ou de lesóes corporais graves ou gravissimas", ponderou Salomão. Ainda segundo o ministro, "franquear a via das açóes de natureza civel, com aplicação de medidas protetivas da Lei Maria da Penha, pode evitar um mal maior, sem necessidade de posterior intervenção penal nas relações intrafamiliares". A ação protetiva dos direitos da mulher foi ajuizada por uma senhora contra um de seus seis filhos. Segundo o processo, após doações de bens feitas em 2008 por ela e o 
marido aos filhos, um deles passou a tratar os pais de forma violenta, com xingamentos, ofensas e até ameaças de morte. $\mathrm{O}$ marido faleceu. Com a ação, a mulher pediu a aplicação de medidas protetivas previstas na Lei Maria da Penha. Queria que o filho fosse impedido de se aproximar dela e dos irmãos no limite mínimo de cem metros de distância, e de manter contato com eles por qualquer meio de comunicação até a audiência. Queria ainda a suspensão da posse ou restrição de porte de armas. Em primeira instância, o processo foi extinto sem julgamento de mérito. $\mathrm{O}$ juiz considerou que as medidas protetivas da Lei Maria da Penha têm natureza processual penal e são vinculadas a um processo criminal. Não há ação penal no caso. O Tribunal de Justiça de Goiás reformou a sentença e aplicou as medidas protetivas, por entender que elas têm caráter civil. O filho apontado como agressor recorreu ao Superior Tribunal de Justiça contra essa decisão. Segundo o Ministro Luis Felipe Salomão, a Lei Maria da Penha permite a incidência do artigo 461, $§ 5^{\circ}$., do Código de Processo Civil para concretização das medidas nela previstas. Ele entendeu que, de forma recíproca e observados os requisitos específicos, é possível a aplicação da Lei 11.340 no âmbito do processo civil.

Seguindo o voto do relator, a Turma decidiu, por unanimidade de votos, que as medidas protetivas da Lei Maria da Penha, observados os requisitos para concessão de cada uma, podem ser pedidas de forma autônoma para fins de cessação ou de acautelamento de violência doméstica contra a mulher, independentemente da existência, presente ou potencial, de processo-crime ou ação principal contra o suposto agressor. Nessa hipótese, as medidas de urgência terão natureza de cautelar cível satisfativa. (Com informações da Assessoria de Imprensa do Superior Tribunal de Justiça.

\section{V - OS JUIZADOS DE VIOLÊNCIA DOMÉSTICA E FAMILIAR}

A lei prevê a criação e implementação dos Juizados de Violência Doméstica e Familiar contra a Mulher, que "poderá ser acompanhada pela implantação das curadorias necessárias e do serviço de assistência judiciária”; enquanto não existirem tais Juizados, "as varas criminais acumularão as 
competências civel e criminal para conhecer e julgar as causas decorrentes da prática de violência doméstica e familiar contra a mulher."

Convenhamos ser bastante estranho (no mínimo), inclusive do ponto de vista do princípio constitucional do Juiz Natural, esta competência cível "delegada" a um Juiz com competência criminal!

O Juiz Natural é aquele constitucional, legal e previamente competente para julgar determinada causa criminal, imparcial e independente, garantindo-se-lhe a inamovibilidade (arts. 95, II e 93, VIII, $\mathrm{CF} / 88$ ), a irredutibilidade de vencimentos (art. 95, III, CF/88) e a vitaliciedade (art. 95, I, CF/88).

Vejamos a lição de Rogério Lauria Tucci:

“(...) O acesso do membro da coletividade à Justiça Criminal reclama, também como garantia inerente ao 'due processo of law' especificamente no processo criminal, a preconstituição do órgão jurisdicional competente, sintetizada, correntemente, na dicção do juiz natural (...) É por isso, aliás, que incidente ao processo penal a máxima 'tempus criminis regit iudicem', deve prevalecer, para o conhecimento e julgamento das causas criminais, a organização judiciária preexistente à prática da infração penal; (...) Ao imputado confere (a garantia do juiz natural) a certeza da inadmissibilidade de processamento da causa e julgamento por juiz ou tribunal distinto daquele tido por competente à época da prática da infração penal." 28

Para Edgar Silveira Bueno, o Princípio do Juiz Natural “teve origem, segundo afirma Luiz Gustavo Grandinetti Castanho de Carvalho, citando Ernst Beling: 'como limitação do poder absoluto e para aprofundar a distinção entre a administração e a justiça, cuja necessidade já se impunha desde o Iluminismo. Nesse periodo, frequentemente o rei, o principe, enfim, o chefe de Estado, intrometia-se no Judiciário, delegava suas atribuições a outras pessoas e impedia, assim, que o órgão com atribuição específica para julgar se pronunciasse em determinado processo (...) Essa foi, em sintese, a razão fundamental da instituição do princípio do juiz natural ! (...) Há dois dispositivos constitucionais que asseguram o respeito ao principio do juiz natural em nosso texto magno. São as regras do art. 5०, XXXVII e LIII, segundo as quais não se

28 Direitos e Garantias Individuais no Processo Penal Brasileiro, São Paulo: Saraiva, 1993, p.121/123. 
admite no Brasil a existência de juízo ou Tribunal de excę̧ão e impóe-se que as pessoas só podem ser processadas e julgadas pelas autoridades competentes. Esses dispositivos servem para garantir ao individuo que nenhum juizo ou tribunal será criado para apurar um delito que já foi praticado." ${ }^{29}$

Ada Grinover, Cândido Rangel Dinamarco e Antonio Carlos de Araújo Cintra afirmam que "as modernas tendências sobre o principio do juiz natural nele englobam a proibição de subtrair o juiz constitucionalmente competente. Desse modo, a garantia desdobra-se em três conceitos: a) só são órgãos jurisdicionais os instituidos pela Constituição; b) ninguém pode ser julgado por órgão constituido após a ocorrência do fato; c) entre os juizes pré-constituídos vigora uma ordem taxativa de competências que exclui qualquer alternativa à discricionariedade de quem quer que seja. (...) Entende-se que as alterações da competência introduzidas pela própria Constituição após a prática do ato de que alguém é acusado não deslocam a competência criminal para o caso concreto, devendo o julgamento ser feito pelo órgão que era competente ao tempo do fato (em matéria penal e processual penal, há extrema preocupação em evitar que o acusado seja surpreendido com modificações posteriores ao momento em que ofato foi praticado)." ${ }^{30}$

Em um balanço apresentado no dia 30 de março de 2009, em Brasília, pelo Conselho Nacional de Justiça sobre a aplicação da Lei Maria da Penha mostra que o número de processos em tramitação por violência doméstica contra mulheres chegou a 150.532 entre julho e novembro de 2008. Dos processos abertos, 75.829 já foram sentenciados. Ao todo foram abertas 41.957 ações penais e 19.803 ações cíveis, além de 19.400 medidas protetivas - aquelas concedidas para proteger vítimas de agressão - e 11.175 agressores presos em flagrante. A chamada $3^{\mathrm{a}}$ Jornada de Trabalho sobre a Lei Maria da Penha avaliou a situação das Varas de Violência Doméstica e Familiar nos Estados. Em relação à última jornada, realizada no ano de 2008, o número de Estados que agora apresentam varas ou juizados especiais para combater a agressão doméstica à mulher subiu de 17 para 22, mais o Distrito Federal. Segundo o CNJ, os Estados que ainda não têm o serviço são Roraima, Amapá, Tocantins e Paraíba.

29 O Direito à Defesa na Constituição, São Paulo: Saraiva, 1994, p. 33.

30 Teoria Geral do Processo, São Paulo: Malheiros, 1995, p. 52. 
O secretário de Reforma do Judiciário, Rogério Favreto, afirmou que, no ano passado, o Ministério da Justiça chegou a investir $\mathrm{R} \$$ 16,8 milhões na implantação de sete varas especializadas e que os órgãos são "estratégicos" para o enfrentamento do tema. "O juizado é um órgão agregador e referencial no sentido de responder e enfrentar a criminalidade, com estrutura multidisciplinar e interligação com os serviços públicos que recebem as medidas protetivas determinadas pelos juizes", disse Favreto.

O Presidente do Supremo Tribunal Federal, Gilmar Mendes, que esteve no evento que divulgou os números, admitiu que há dificuldades em realizar "transformaçôes culturais" a partir de iniciativas jurídicas. "A Lei Maria da Penha tem essa pretensão", disse, ao destacar que as pessoas têm dificuldade de denunciar e de obter algum tipo de proteção em uma relação "extremamente complexa”. A conselheira Andrea Pachá, presidente da Comissão de Acesso à Justiça e Juizados Especiais do $\mathrm{CNJ}$, reforçou que os dados apresentados ainda não estão consolidados. A expectativa do CNJ, segundo ela, é que, com a criação de um fórum permanente para debater o assunto, números que indiquem a quantidade e o tipo de condenações, além do perfil do agressor, sejam divulgados. "São só indicativos. Nossa prioridade em 2008 foi a instalação das varas e a formação dos profissionais", afirmou. Fonte: Agência Brasil (30/03/2009).

De toda maneira, observar que "não sendo o caso de violência de gênero, caracterizada pela ação ou omissão que revele uma concepção de dominação, de poder ou submissão do sujeito ativo contra a mulher, afasta-se a incidência projetiva da lei Maria da Penha e, de consequência, a competência do juizado de violência doméstica e familiar contra a mulher, para determinar a remessa dos autos ao juízo comum, após declarada a nulidade do processo desde o recebimento da denúncia, inclusive. Processo nulo. Remessa ao juizo comum." (TJGO - 2a C. AP 34734-2/213 - rel. Nelma Branco Ferreira Perilo - j. 14.04.2009 - DOE 28.04.2009).

\section{VI - AAPLICAÇÃO DA LEI Nº 9.099/95}

Agora vejamos o art. 41 da lei, certamente o que vem causando o mais acirrado debate na doutrina. Segundo este dispositivo, "aos crimes praticados com violência doméstica e familiar contra a mulher, independentemente da pena prevista, não se aplica a Lei no 9.099, de 26 de setembro de 1995." 
Entendemos tratar-se de artigo inconstitucional. Valem as mesmas observações expendidas quando da análise do art. 17. São igualmente feridos princípios constitucionais (igualdade e proporcionalidade). Assim, para nós, se a infração penal praticada for um crime de menor potencial ofensivo (o art. 41 não se refere às contravenções penais) devem ser aplicadas todas as medidas despenalizadoras previstas na Lei no. 9.099/95 (composição civil dos danos, transação penal e suspensão condicional do processo), além da medida "descarcerizadora" do art. 69 (Termo Circunstanciado e não lavratura do auto de prisão em flagrante, caso o autor do fato comprometa-se a comparecer ao Juizado Especial Criminal).

Seguindo o mesmo raciocínio, em relação às lesões corporais leves e culposas, a ação penal continua a ser pública condicionada à representação, aplicando-se o art. 88 da Lei no. 9.099/95.

Cremos que devemos interpretar tal dispositivo à luz da Constituição Federal e não o contrário. Afinal de contas, como já escreveu Cappelletti, "a conformidade da lei com a Constituição é o lastro causal que a torna válida perante todas." ${ }^{1}$ Devemos interpretar as leis ordinárias em conformidade com a Carta Magna, e não o contrário! Segundo Frederico Marques, a Constituição Federal "não só submete - legislador ordinário a um regime de estrita legalidade, como ainda subordina todo o sistema normativo a uma causalidade constitucional, que é condição de legitimidade de todo o imperativo jurídico." ${ }^{32}$

A prevalecer a tese contrária (pela constitucionalidade do artigo), uma injúria praticada contra a mulher naquelas circunstâncias não seria infração penal de menor potencial ofensivo (interpretando-se o art. 41 de forma literal); já uma lesão corporal leve, cuja pena é o dobro da injúria, praticada contra um idoso ou uma criança (que também mereceram tratamento diferenciado do nosso legislador - Lei no. 10.741/03 e Lei no. 8.069/90) é um crime de menor potencial ofensivo.

31 Apud José Frederico Marques, Elementos de Direito Processual Penal, Campinas: Bookseller, 1998, Vol. I, p. 79.

32 Elementos de Direito Processual Penal, Vol. I, Campinas: Bookseller, 1998, p. 79. 
No primeiro caso, o autor da injúria será preso e autuado em flagrante, responderá a inquérito policial, haverá queixa-crime, etc., etc. Já o segundo agressor não será autuado em flagrante, será lavrado um simples Termo Circunstanciado, terá a oportunidade da composição civil dos danos, da transação penal e da suspensão condicional do processo, etc., etc. (arts. 69, 74, 76 e 89 da Lei no. 9.099/95). Outro exemplo: em uma lesão corporal leve praticada contra uma mulher a ação penal independe de representação (é pública incondicionada), mas uma lesão corporal leve cometida contra um infante ou um homem de 90 anos depende de representação. Outro exemplo: um pai agride e fere levemente seus dois filhos gêmeos, um homem e uma mulher; receberá tratamento jurídico-criminal diferenciado. Onde nós estamos!

Nada obstante, decidiu o Superior Tribunal de Justiça que autores de violência doméstica contra mulheres podem ser processados pelo Ministério Público, independentemente de autorização da vítima. A conclusão, por maioria, é da Sexta Turma do Superior Tribunal de Justiça, ao considerar que a ação penal contra o agressor deve ser pública incondicionada. No recurso especial dirigido ao STJ, o Ministério Público do Distrito Federal e Territórios protestava contra o trancamento da ação penal contra o agressor E.S.O., do Distrito Federal. Após a retratação da vítima em juízo, afirmando não querer mais perseguir criminalmente o agressor, o Tribunal de Justiça do Distrito Federal e Territórios (TJDFT) trancou a ação, afirmando que não haveria justa causa para o seu prosseguimento. Segundo o TJDFT, os delitos de lesões corporais leves e culposas continuam tendo a natureza jurídica de pública condicionada à representação, pois o sistema processual brasileiro tem regência da unicidade. "Não havendo a possibilidade jurídica para o prosseguimento da ação penal, em face das disposições do artigo 16 da Lei 'Maria da Penha', qual seja, a manifestação da vítima perante o juiz de não mais processar o seu companheiro, concede-se a ordem de habeas corpus para determinar-se o trancamento da ação penal por faltar-lhe a justa causa”, afirmou a decisão do Tribunal de Justiça do Distrito Federal.

$\mathrm{Na}$ decisão, o tribunal brasiliense ressalvou, ainda, a possibilidade de a vítima, a qualquer momento, no prazo de seis meses, voltar a exercer o direito de denunciar o agressor. Para o Ministério Público, no 
entanto, a decisão ofendeu os artigos 13,16 e 41 da Lei Maria da Penha, além dos artigos 648, I, e 38 do Código de Processo Penal, artigo 88 da Lei n. 9.0909/95 e os artigos 100 e 129, parágrafo 9, do Código Penal. Requereu, então, a reforma da decisão, alegando que a ação penal do presente delito tem natureza pública incondicionada, não sendo dependente da representação da vítima. Em parecer sobre o caso, o Ministério Público Federal observou que a Lei Maria da Penha prescreve, em seu artigo 41, que não se aplica a Lei n. 9.099/95 aos crimes praticados com violência doméstica e familiar contra a mulher.

Segundo o Ministério Público Federal, deve ser reconhecido o direito do Estado em dar prosseguimento à ação penal, vez que esta não depende de representação da vítima, devendo ser reconhecida a justa causa para a perseguição criminal do agressor. A relatora do caso, a Desembargadora convocada Jane Silva, concordou com os argumentos e foi acompanhada pelo ministro Paulo Gallotti. Os ministros Nilson Naves e Maria Theresa de Assis Moura divergiram. Em seu voto-vista, o ministro Og Fernandes desempatou em favor da tese do Ministério Público: a ação contra autores de violência doméstica contra a mulher deve ser pública incondicionada. $\mathrm{O}$ mesmo resultado foi adotado para o Recurso Especial 1.050.276, também do Distrito Federal.

Em julgamento posterior, no entanto, o Superior Tribunal de Justiça decidiu contrariamente: "A Turma, ao prosseguir o julgamento, por maioria, concedeu a ordem de habeas corpus, mudando o entendimento quanto à representação prevista no art. 16 da Lei n. 11.340/2006. Considerou que, se a vitima só pode retratar-se da representação perante o juiz, a ação penal é condicionada. Ademais, a dispensa de representação significa que a ação penal teria prosseguimento e impediria a reconciliação de muitos casais." (HC 113.608-MG, Rel. originário Min. Og Fernandes, Rel. para acórdão Min. Celso Limongi - Desembargador convocado do TJ-SP, julgado em 5/3/2009).

Também alguns tribunais estaduais:

"A incidência irrestrita da Lei 11.340/06 para tutelar, além da mulher adulta, a criança do sexo feminino, importa em proteção superlativa, com ofensa direta aos princípios constitucionais da isonomia e da razoabilidade. A vulnerabilidade e a bipossuficiência de tal categoria, jus- 
tificativa do tratamento legal especial, diferentemente do que ocorre com a mulher adulta, independe do gênero sexual, não servindo, os arts. $2^{\circ}$. e 13․ daquele diploma, como fundamento adequado para ilaçóes em sentido contrário. Conflito negativo julgado improcedente, competente o juizo da 12a. Vara Criminal de Goiânia." (TJGO - 2a C. - rel. Marcio de Castro Molinari-j. 01.04.2009).

"A lei $n$ 11.340/06 (Lei Maria da Penha), não retirou a faculdade de representação da vitima, haja vista a possibilidade de renúncia. Desde modo, não se há falar em ação pública incondicionada nos casos de lesôes corporais oriundas de violência doméstica. Assim, havendo retratação da representação em audiência designada para tal finalidade, antes do recebimento da denúncia, o não recebimento da mesma e arquivamento dos autos é medida que se impóe, ante e falta de procedibilidade para a ação penal. Recurso ministerial improvido" (TJMG - 5a C. - RESE 1.0024.07.759594-0/001(1) - rel. Adilson Lamounier - j. 23.09.2008 - DOE 06.10.2008).

"A Lei Maria da Penha não retirou a faculdade de representação da ofendida nos crimes de lesão corporal, nem transformou a ação penal em incondicionada, uma vez que o artigo 16 da Lei 11. 340/06 faculta a renúncia à representação da vítima. Nas ações penais públicas condicionadas à representação, considera-se não satisfeita a condição de procedibilidade diante da ausência de demonstração inequivoca de intenção da vitima em ver deflagrada a ação penal conta o ofensor, não bastando a mera narrativa dos fatos ocorridos" (TJMG - 5a C. - RESE 1.0210.08.048129-9/001(1) - rel. Adilson Lamounier - j. 20.01.2009 - DOE 02.02.2009).

Nada obstante, insistimos que o princípio da proporcionalidade não foi observado, o que torna inválida esta norma (como também a do art. 17), apesar de vigente.

Como observa Mariângela Gama de Magalhães Gomes, este princípio "desempenha importante função dentro do ordenamento jurídico, não apenas penal, uma vez que orienta a construção dos tipos incriminadores por meio de uma criteriosa seleção daquelas condutas que merecem uma tutela diferenciada (penal) e das que não a merecem, assim como fundamenta a diferenciação nos tratamentos penais dispensados às diversas modalidades delitivas; além disso, conforme enunciado, constitui importante 
limite à atividade do legislador penal (e também do seu intérprete), posto que estabelece até que ponto é legitima a intervenção do Estado na liberdade individual dos cidadãos." 33

Para Pedraz Penalva, "a proporcionalidade é, pois, algo mais que um critério, regra ou elemento técnico de juizo, utilizável para afirmar conseqüências jurídicas: constitui um princípio inerente ao Estado de Direito com plena e necessária operatividade, enquanto sua devida utilização se apresenta como uma das garantias básicas que devem ser observadas em todo caso em que possam ser lesionados direitos e liberdades fundamentais." ${ }^{4}$

Feriu-se, outrossim, o princípio da igualdade, previsto expressamente no art. $5^{\circ}$., caput da Constituição Federal. Este princípio constitucional "significa a proibição, para o legislador ordinário, de discriminações arbitrárias: impóe que a situações iguais corresponda um tratamento igual, do mesmo modo que a situaçôes diferentes deve corresponder um tratamento diferenciado."

Segundo ainda Mariângela Gama de Magalhães Gomes, a igualdade "ordena ao legislador que preveja com as mesmas conseqüências juridicas os fatos que em linha de principio sejam comparáveis, e lhe permite realizar diferenciaçôes apenas para as hipóteses em que exista uma causa objetiva - pois caso não se verifiquem motivos desta espécie, haverá diferenciações arbitrárias." ${ }^{5}$

Para Ignacio Ara Pinilla, "la preconizada igualdad de todos frente a la ley (...) ha venido evolucionando en un sentido cada vez más contenutista, comprendiédose paulatinamente como interdicción de discriminaciones, o, por lo menos, como interdicción de discriminaciones injustificadas." ${ }^{36}$

33 O Princípio da Proporcionalidade no Direito Penal, São Paulo: Editora Revista dos Tribunais, 2003, p. 59.

34 Apud Mariângela Gama de Magalhães Gomes, "O Princípio da Proporcionalidade no Direito Penal”, São Paulo: Editora Revista dos Tribunais, 2003, p. 60.

35 Obra citada, p. 67.

36 "Reflexiones sobre el significado del principio constitucional de igualdad", artigo que compõe a obra coletiva denominada "El Principio de Igualdad", coordenada por Luis García San Miguel, Madri: Dykinson, 2000, p. 206. 
Como ensina Celso Antônio Bandeira de Mello, "há ofensa ao preceito constitucional da isonomia quando a norma singulariza atual e definitivamente um destinatário determinado, ao invés de abranger uma categoria de pessoas, ou uma pessoa futura e indeterminada." ${ }^{37}$

Mas, infelizmente, como afirma Francesco Palazzo, "a influência dos valores constitucionais vem, pouco a pouco, crescendo sempre no arco dos tempos, sem que, no entanto, ainda assim as transformaçôes constitucionais tenham logrado produzir a esperada reforma orgânica do sistema penal, inclusive." 38

Canotilho explica que são "principios jurídicos fundamentais os principios historicamente objectivados e progressivamente introduzidos na consciência jurídica e que encontram uma recepção expressa ou implícita no texto constitucional. Pertencem à ordem jurídica positiva e constituem um importante fundamento para a interpretação, integração, conbecimento e aplicação do direito positivo." 39

Este art. 41 também afronta o disposto no art.98,I da Constituição Federal, pois a competência dos Juizados Especiais Criminais é ditada pela natureza da infração penal, estabelecida em razão da matéria e, portanto, de caráter absoluto, ainda mais porque tem base constitucional; neste sentido, Mirabete e Ada, respectivamente:

"A competência do Juizado Especial Criminal restringe-se às infraçôes penais de menor potencial ofensivo, conforme a Carta Constitucional e a lei. Como tal competência é conferida em razão da matéria, é ela absoluta." 40

"A competência do Juizado, restrita às infraçôes de menor potencial ofensivo, é de natureza material e, por isso, absoluta." ${ }_{11}$

37 Conteúdo Jurídico do Princípio da Igualdade, São Paulo: Malheiros, 1999, $3^{\mathrm{a}}$. ed., 6 $6^{\mathrm{a}}$. tiragem, p. 47.

38 Valores Constitucionais e Direito Penal, Porto Alegre: Sergio Antonio Fabris Editor, 1989, p. 117.

39 Direito Constitucional e Teoria da Constituição, Coimbra: Almedina, 6a ed., p. 1.151.

40 Juizados Especiais Criminais, São Paulo: Atlas, 1997, p. 28.

${ }^{41}$ Juizados Especiais Criminais, São Paulo: Editora Revista dos Tribunais, 2a . ed., p. 69. 
Igualmente Cezar Roberto Bitencourt, para quem "a competência ratione materiae, objeto de julgamento pelos Juizados Especiais Criminais, apresenta-se da seguinte forma: crimes com pena máxima cominada não superior a dois anos e contravenções penais." "42

Sidney Eloy Dalabrida também já escreveu:

"A competência do Juizado Especial Criminal foi firmada a nivel constitucional (art. 98, I, CF), restringindo-se à conciliação (composição e transação), processo, julgamento e execução de infrações penais de menor potencial ofensivo. É competência que delimita o poder de julgar em razão da natureza do delito (ratione materiae), e, sendo assim, absoluta." ${ }^{43}$

Repita-se que a competência da qual ora falamos tem índole constitucional (art. 98, I da Carta Magna), sendo nulos todos os atos porventura praticados, não somente os decisórios, como também os probatórios, "pois o processo é como se não existisse."

Se assim o é, ou seja, se a própria Constituição estabeleceu a competência dos Juizados Especiais Criminais para o processo, julgamento e execução das infrações penais de menor potencial ofensivo, é induvidoso não ser possível a exclusão desta competência em razão do sujeito passivo atingido (mulher) e pela circunstância de se tratar de violência doméstica e familiar.

É bem verdade que a própria Lei no. 9.099/95 prevê duas hipóteses em que é afastada a sua competência (arts. 66, parágrafo único e 77 , § $2^{\circ}$.), mas este fato não representa obstáculo ao que dissemos, pois se encontra dentro da faixa de disciplina possível para a Lei $\mathrm{n}^{\circ}$. 9.099/95, permitida pelo art. 98 da Constituição. Em outras palavras: ao delimitar a competência dos Juizados, poderia a respectiva lei, autorizada pela Lei Maior, estabelecer exceções à regra, observando, evidentemente, os critérios orientadores estabelecidos pela própria lei. Efetivamente, na Lei no. 9.099/95 há duas causas modificadoras da

${ }^{42}$ Juizados Especiais Criminais e Alternativas à Pena de Prisão, Porto Alegre: Livraria do Advogado Editora, 3ª ed., p. 59.

43 Boletim do Instituto Brasileiro de Ciências Criminais - IBCCrim, n. ${ }^{\circ}$ 57, agosto/1997.

${ }^{44}$ Fernando da Costa Tourinho Filho, Processo Penal, São Paulo: Saraiva, Vol. II, $12^{\mathrm{a}}$. ed. p. 503. 
competência: a complexidade ou circunstâncias da causa que dificultem a formulação oral da peça acusatória (art. $77, \S 2^{\circ}$.) e o fato do réu não ser encontrado para a citação pessoal (art. 66, parágrafo único). Porém, o certo é que tais disposições não ferem a Constituição Federal, pois as duas hipóteses se ajustam perfeitamente aos critérios da celeridade, informalidade e economia processual propostos pelo legislador (art. 62, Lei no. 9.099/95).

Nada mais razoável e proporcionalmente aceitável que retirar dos Juizados Especiais o réu citado por edital (ao qual será aplicado, caso não compareça, o art. 366 do CPP) e um processo mais complexo: são circunstâncias que, apesar de excluírem a competência dos Juizados, ajustam-se perfeitamente àqueles critérios acima indicados e são, portanto, constitucionalmente aceitáveis.

Observa-se que se as leis respectivas "podem definir quais são as infrações, podem, também, o menos, que é excluir aquelas que, mesmo sendo de menor potencial ofensivo, não são recomendadas para serem submetidas ao Juizado, desde que não se subtraia de todo a competência estabelecida constitucionalmente", como bem anotou Luiz Gustavo Grandinetti Castanho de Carvalho. ${ }^{45}$ (grifo nosso).

Destarte, subtraindo a competência dos Juizados Especiais Criminais, a referida lei incidiu em flagrante inconstitucionalidade, pois a competência determinada expressamente pela Constituição Federal não poderia ter sido reduzida por lei infraconstitucional.

O texto constitucional é explícito ao garantir ao autor da infração penal de menor potencial ofensivo o procedimento oral e sumariíssimo. Segundo Antonio Scarance Fernandes, "a incorporação, nos ordenamentos, de modelos alternativos aos procedimentos comuns ou ordinários gera para as partes o direito a que, presentes os requisitos legais, sejam obrigatoriamente seguidos. (...) Em relação à extensão do procedimento, têm as partes direito aos atos e fases que formam o conjunto procedimental. Em sintese, têm direito à integralidade do procedimento." ${ }^{46}$

45 Lei dos Juizados Especiais Criminais (com Geraldo Prado), Rio de Janeiro: Lumen Juris, 2003, p. 15.

46 Teoria Geral do Procedimento e o Procedimento no Processo Penal, São Paulo: Editora Revista dos Tribunais, 2005, pp. 67/69. 
Ademais, "o procedimento pode ser visto como as regras de um jogo, que devem ser obedecidas para que seja legitima a competição. O cumprimento dos atos e fases procedimentais se impóe tanto ao Juiz quanto às partes e a todos os sujeitos que participarem do processo, isso porque o procedimento é integral. Além disso, prevendo a lei um procedimento específico para determinada relação de Direito Material controvertida, não cabe ao Juiz dispensá-la, impondo-se sua observância, em respeito ao devido processo legal. Justifica-se isso em virtude de os atos previstos na cadeia procedimental serem adequados à tutela de determinadas situações, dai serem imprescindiveis, ou seja, o procedimento ostenta uma tipicidade." 47

A propósito, mutatis mutandis, veja um trecho do voto proferido pelo Ministro Celso de Mello na Ação Direta de Inconstitucionalidade no. 2.797-2:

“(...) Esta Suprema Corte, ao exercer o seu poder de indagação constitucional - consoante adverte CASTRO NUNES ("Teoria e Prática do Poder Judiciário", p. 641/650, 1943, Forense) - deve ter presente, sempre, essa técnica lógico-racional, fundada na teoria jurídica dos poderes implicitos, para, através dela, mediante interpretação judicial (e não legislativa), conferir eficácia real ao conteúdo e ao exercício de dada competência constitucional, consideradas as atribuições do Supremo Tribunal Federal, do Superior Tribunal de Justiça, dos Tribunais Regionais Federais e dos Tribunais de Justiça48, tais como expressamente relacionadas no texto da própria Constituição da República. (...) Vê-se, portanto, que são inconfundiveis - porque inassimiláveis tais situações - a possibilidade de interpretação, sempre legítima, pelo Poder Judiciário, das normas constitucionais que lhe definem a competência e a impossibilidade de o Congresso Nacional, mediante legislação simplesmente ordinária, ainda que editada a pretexto de interpretar a Constituição, ampliar, restringir ou modificar a esfera de atribuiçóes jurisdicionais originárias desta Suprema Corte, do Superior Tribunal de Justiça, dos Tribunais Regionais Federais e dos

47 Luciana Russo, "Devido processo legal e direito ao procedimento adequado", artigo publicado no jornal "O Estado do Paraná", na edição do dia 26 de agosto de 2007.

48 E também dos Juizados Especiais Criminais, cuja competência encontra sede igualmente na Carta Magna. 
Tribunais de Justiça estaduai ${ }^{49}$, por tratar-se de matéria posta sob reserva absoluta de Constituição. (...) Em suma, Senhora Presidente, o Congresso Nacional não pode - simplesmente porque não dispóe, constitucionalmente, dessa prerrogativa - ampliar (tanto quanto reduzir ou modificar), mediante legislação comum, a esfera de competência originária do Supremo Tribunal Federal, do Superior Tribunal de Justiça, dos Tribunais Regionais Federais e dos Tribunais de Justiça dos Estados ${ }^{50}$. (...) O ponto está em que às leis ordinárias não é dado impor uma dada interpretação da Constituição. De tudo resulta que a lei ordinária que se limite a pretender impor determinada inteligência da Constituição é, só por isso, formalmente inconstitucional. (...) Coisa diversa, convém repisar, é a lei pretender impor, como seu objeto imediato, uma interpretação da Constituição: aí, a questão é de inconstitucionalidade formal, insita a toda norma de gradação inferior que se proponha a ditar interpretação de norma de hierarquia superior. (...) Dai a correta lição expendida pelo ilustre magistrado ANDRÉ GUSTAVO C. DE ANDRADE ("Revista de Direito Renovar", vol. 24/78-79, set/dez 02), que também recusa, ao Poder Legislativo, a possibilidade de, mediante verdadeira "sentença legislativa", explicitar, em texto de lei ordinária, o significado da Constituição. Diz esse ilustre autor: 'Na direção inversa - da harmonização do texto constitucional com a lei - haveria a denominada interpretação da Constituição conforme as leis, mencionada por Canotilho como método hermenêutico pelo qual o intérprete se valeria das normas infraconstitucionais para determinar o sentido dos textos constitucionais, principalmente daqueles que contivessem fórmulas imprecisas ou indeterminadas. Essa interpretação de mão trocada se justificaria pela maior proximidade da lei ordinária com a realidade e com os problemas concretos. O renomado constitucionalista português aponta várias críticas que a doutrina tece em relação a esse método hermenêutico, que engendra como que uma 'legalidade da Constituição a sobrepor-se à constitucionalidade das leis'. Tal concepção leva ao paroxismo a idéia de que - legislador exercia uma preferência como concretizador da Constituição. Todavia, o legislador, como destinatário e concretizador da Constituição, não tem o poder de fixar a interpretação 'correta' do texto constitucional.

\footnotetext{
49 Repetimos: e também dos Juizados Especiais Criminais.

50

Idem.
} 
Com efeito, uma lei ordinária interpretativa não tem força jurídica para impor um sentido ao texto constitucional, razão pela qual deve ser reconhecida como inconstitucional quando contiver uma interpretação que entre em testilha com este."

Diante do exposto, este dispositivo da nova lei não deve ser aplicado pelo Juiz, pois, como se sabe, o controle de constitucionalidade judiciário no Brasil tem o caráter difuso ${ }^{51}$, podendo "perante qualquer juiz ser levantada a alegação de inconstitucionalidade e qualquer magistrado pode reconhecer essa inconstitucionalidade e em conseqüência deixar de aplicar o ato inquinado", na lição do constitucionalista Manoel Gonçalves Ferreira Filho. ${ }^{52}$

No Superior Tribunal de Justiça já se decidiu que "o controle jurisdicional da constitucionalidade, no regime da constituição vigente, pode ser exercitado via de defesa (difuso), incidentur tantum, por todos os juizes, com efeitos inter partes." (STJ, 1․ T., ROMS no. 746/RJ, Rel. Min. Milton Luiz Pereira, Diário da Justiça, Seção I, 05/10/93, p. 22.451. RSTJ 63/137).

Obviamente, mais uma vez não se observou o princípio da proporcionalidade ${ }^{53}$, perfeitamente exigível quando se trata de estabelecer requisitos e pressupostos para a prisão provisória; aqui, prende-se preventivamente quando, muito provavelmente, não haverá aplicação de uma pena privativa de liberdade (quando da sentença condenatória).

Como ensina Alberto Bovino, não é possível "que a situação do individuo ainda inocente seja pior do que a da pessoa já condenada, é dizer, de proibir que a coerção meramente processual resulte mais gravosa que a

51 Segundo José Afonso da Silva, entre nós, este "sistema foi originariamente instituido com a Constituição de 1891 que, sob a influência do constitucionalismo norte-americano, acolhera o critério de controle difuso por via de exceção, que perdurou nas constituiçôes sucessivas até a vigente." (Curso de Direito Constitucional Positivo, São Paulo: Malheiros, 10ª. ed., 1995).

52 Curso de Direito Constitucional, São Paulo: Saraiva, 17a. ed., 1989, p. 34.

53 Como afirma Denilson Feitoza Pacheco, "a importância da afetação negativa causada pela medida cautelar pessoal deve estar justificada pela importância da realização do fim perseguido por essa intervenção no direito fundamental." (O Princípio da Proporcionalidade no Direito Processual Penal Brasileiro, Rio de Janeiro: Lumen Júris, 2007, p. 261). 
própria pena. Em conseqüência, não se autoriza o encarceramento processual, quando, no caso concreto, não se espera a imposição de uma pena privativa de liberdade de cumprimento efetivo. Ademais, nos casos que admitem a privação antecipada da liberdade, esta não pode resultar mais prolongada que a pena eventualmente aplicável. Se não fosse assim, o inocente se acharia, claramente, em pior situação do que o condenado. "54

Segundo Humberto Ávila, "um meio é proporcional quando o valor da promoção do fim não for proporcional ao desvalor da restrição dos direitos fundamentais. Para analisá-lo é preciso comparar o grau de intensidade da promoção do fim com o grau de intensidade da restrição dos direitos fundamentais. O meio será desproporcional se a importância do fim não justificar a intensidade da restrição dos direitos fundamentais." 55

Aliás, no art. 20 da lei já se prevê que "em qualquer fase do inquérito policial ou da instrução criminal, caberá a prisão preventiva do agressor, decretada pelo juiz, de ofício, a requerimento do Ministério Público ou mediante representação da autoridade policial", podendo o Juiz “revogar a prisão preventiva se, no curso do processo, verificar a falta de motivo para que subsista, bem como de novo decretá-la, se sobrevierem razóes que a justifiquem." Note-se, porém, que com o advento da Lei no. 12.403/2011, que deu nova redação ao art. 311 do Código de Processo Penal, o Juiz só pode decretar de ofício a prisão preventiva no curso do processo penal. Antes, apenas quando requerida pelo Ministério Público ou representada pela autoridade policial.

\section{VII - CONCLUSÃO}

Diante destas considerações, entendemos que os arts. 17 e 41 da Lei no. 11.340/2006, além do inciso IV do art. 313 do Código de Processo Penal, não devem ser aplicados, pois, apesar de normas vigentes formalmente (porque aprovadas pelo Poder Legislativo e promulgadas pelo Poder Executivo), são substancialmente inválidas, ten-

54 Apud Rogerio Schietti Machado Cruz, "Prisão Cautelar - Dramas, Princípios e Alternativas”, Rio de Janeiro: Lumen Juris, 2006, p. 100.

55 Teoria dos Princípios, São Paulo: Malheiros, 4a ed., 2004, p. 131. 
do em vista a incompatibilidade material com a Constituição Federal. Relembremos que "não se pode interpretar a Constituição conforme a lei ordinária (gesetzeskonformen Verfassunsinterpretation). O contrário é que se faz." ${ }^{56}$

Uma coisa é lei vigente, outra é lei válida.

Vejamos a lição de Miguel Reale:

"Validade formal ou vigência é, em suma, uma propriedade que diz respeito à competência dos órgãos e aos processos de produção e reconhecimento do Direito no plano normativo." ${ }^{7}$

Nem toda lei vigente é válida e só a lei válida e que esteja em vigor deve ser observada pelos cidadãos e operadores de Direito. ${ }^{58}$

Como afirma Enrique Bacigalupo, "la validez de los textos y de las interpretaciones de los mismos dependerá de su compatibilidad con principios superiores. De esta manera, la interpretación de la ley penal depende de la interpretación de la Constitución." 59

A propósito, Ferrajoli:

"Para que una norma exista o esté en vigor es suficiente que satisfaga las condiciones de validez formal, condiciones que hacen referencia a las formas y los procedimientos de acto normativo, así como a la competência del órgano de que emana. Para que sea válida se necesita por el contrario que satisfaga también las condiciones de validez sustancial, que se refieren a su contenido, o sea, a su significado." Para o autor, "las condiciones sustanciales de la validez, y de manera especial las de la validez constitucional,

56 STJ, Rel. Min. ADEMAR MACIEL, DJU 3.4.95, p.8.149.

${ }^{57}$ Lições Preliminares de Direito, São Paulo: Saraiva, 19ª. ed., 1991, p. 114.

58 Como ensina Gilberto Thums, "não basta que existam leis com vigência, é necessário que sejam válidas e somente possuem validade as leis que se harmonizam com os principios fundamentais da Constituição. (...) Portanto, todas as normas infraconstitucionais que não correspondem, quanto ao seu conteúdo, aos principios constitucionais, embora formalmente vigentes (validade formal), seriam materialmente inconstitucionais, podendo o juiz negar sua aplicą̧ão." (Sistemas Processuais Penais, Rio de Janeiro: Lumen Juris, 2006, p. 172, com grifo nosso).

59 "Principios Constitucionales de Derecho Penal", Buenos Aires: Editorial Hamurabi, 1999, p. 232. 
consisten normalmente en el respeto de valores - como la igualdad, la libertad, las garantias de los derechos de los ciudadanos." ${ }^{60}$ (Grifos no original).

Janaína Paschoal adverte: "O perigo que vislumbramos na nova lei é justamente o de, novamente, prevalecer o caminho mais fácil, qual seja o de simplesmente prender-se o agressor, tratando-se como uma safada` que gosta de apanhar que, depois de denunciar, se opóe a essa prisão. (...) A idéia de que a Mulher precisa se libertar, psicologicamente, de seu agressor é totalitária, e tão preconceituosa como a que deve se submeter às vontades do marido."61

Não olvidemos, outrossim, que a exclusão do Juizado Especial Criminal para o processo e julgamento de tais crimes só facilitará o transcurso do prazo prescricional (e a extinção da punibilidade), pois, optando por outros procedimentos (especiais ou sumário) certamente a demora na aplicação da pena será bem maior do que, por exemplo, se houvesse a possibilidade (bem ou mal) da transação penal (com a proposta imediata de uma pena alternativa).

Segundo o jornal Folha de São Paulo, edição on line do dia 07 de agosto de 2008, "o número de denúncias de agressóes a mulheres no país mais do que dobrou no comparativo do primeiro semestre deste ano em relação a igual período de 2007. Números apresentados nesta quinta-feira pela Secretaria Especial de Politicas para as Mulheres com base no número de serviço 180 --a central de atendimento à mulher-- apontam que de janeiro a junho de 2008 foram feitos 121.891 contra 58.417 em igual periodo de 2007, num incremento de 107,9\%. A lei Maria da Penha, que pune com mais rigidez os agressores de mulheres, completa dois anos hoje. Os dados mostram ainda um crescimento quase três vezes e meio superior na quantidade de pessoas que pretendem se informar sobre a lei. Enquanto no primeiro semestre do ano passado 11.020 ligaçôes foram atendidas com o intuito de prestar esclarecimentos sobre a lei, no primeiro semestre de 2008 os atendimentos foram de 49.025. Distrito Federal, São Paulo, Pará e Goiás lideram o ranking das denúncias. Na outra ponta estão Acre, Maranhão e Amazonas. O levantamento mostra que 61,5\% das mulheres informaram sofrer agressões diariamente e outras $17,8 \%$ são alvo toda semana de destratos. A maior parte das agressões

${ }^{60}$ Derecho y Razón - Teoria del Garantismo Penal, Madri: Editorial Trotta S.A., 3a. ed., 1998, p. 874.

${ }^{61}$ Obra citada, p. 3. 
(63,9\%) são praticadas pelos próprios companheiros. Em 58,4\% dos casos relatados, os agressores estavam bêbados ou eram usuários de drogas. Segundo a subsecretária Aparecida Gonçalves, da área de Enfrentamento à Violência da Secretaria Especial de Politicas para as Mulheres, a maior incidência de denúncias na região Centro-Oeste do país se deve ao que ela considera um maior nivel de informação a respeito da legislação que estabelece maior rigor nas punições aos agressores de mulheres. Isso relativiza o fato de Estados do extremo do país apareçam nas últimas colocações. "A cada ano temos uma maior divulgação da lei, e a medida que ela passa a ter uma maior efetividade, isso reflete nas denúncias. Só as respostas efetivas aos casos de agressões virão a fortalecer esses números", afirma Gonçalves. Apesar de a maior parcela das agressões ser cometida quando o parceiro está drogado ou bêbado, ela afirma que a questão é cultural. "Se fosse só a agressão em si, ele [agressor] bateria num amigo do bar, não na mulher, ao chegar em casa", afirma. Durante cerimônia ocorrida no Palácio do Planalto, foram mostrados também os resultados de uma pesquisa a respeito da lei Maria da Penha. A pesquisa Ibope/Themis (Assessoria Jurídica e Estudos de Gênero) --esta última uma ONG gaúcha-- revelou que $68 \%$ da população brasileira já ouviu falar da lei. Outros $82 \%$ conhecem a sua eficácia. A consulta foi realizada entre os dias 17 e 21 de julho, com 2.002 entrevistados em 142 municípios brasileiros. A margem de erro é de dois pontos percentuais para mais ou para menos. A pesquisa mostra que 32\% não conhece e nem ouviu falar da lei. Um quinto dos pesquisados (20\%) respondeu acreditar que a lei Maria da Penha coloca o agressor na cadeia e 33\% afirmaram que ela inibe a violência doméstica. Após ser agredida, segundo os respondentes, 38\% das mulheres procuram as delegacias especializadas de atendimento à mulher e 19\% outras delegacias. Para $42 \%$ dos entrevistados, as mulheres não procuram serviço de apoio."

A título de conclusão, e para refletirmos, oportuna também a transcrição da lição de Roberta Toledo Campos:

"O homem exalta a violência. Virou o grande monstro que ameaça a familia. O povo grita por socorro. E o Estado, num ato salvacionista, edita a Lei Maria da Penha. Lógico! Como é inadimplente na implementação dos direitos fundamentais, como educação, saúde, moradia, cultura, emprego etc., $e$, assim, gerador de muitas das mazelas humanas, faz uso de uma de suas atribuiçôes a mais viável economicamente: o processo legislativo e o sistema penal. Ao criar leis, o Estado transmite ao povo carente de direitos fundamen- 
tais a sensação de dever cumprido, já que as leis entram em vigor imediatamente e induzem a ilusão de que agora temos leis fortes, que não deixam mais brechas para a impunidade. (...) Não nos escapa que é momento de refletir sobre a crise da masculinidade e da feminilidade. Há dúvida de que a natureza determina de modo tão sumário a diferença entre masculino e feminino. Homem, mulher, masculino e feminino são construçôes. Efetivamente, muitos de nós criticamos o modelo masculino ou feminino sob o qual fomos criados. Já se sabe atualmente que é possivel ser homem sem ser macho e opressor. $O$ desmoronamento dos modelos tradicionais de gênero é mais uma possibilidade do que uma perda. É a possibilidade de mudança. Eé esta crise que nos leva à auto-reflexão para a construção de um novo ser humano. Ser humano este não determinado por sua biologia, mas capaz de encontrar livremente a sua própria identidade, o seu ser, tomando o cuidado para não cometer o erro de supor a possibilidade de uma nova sintese, de uma nova identidade estereotipada. (...) Não é possível diante da principiologia democrática constitucionalizada estabelecer modelos de identidade masculina ou feminina. Estereotipar a identidade em masculino e feminino é, no mínimo, discriminatório. Falar em encontrar uma nova identidade masculina ou feminina é um equivoco. É possivel apenas refletir sobre a construção da nova identidade do sujeito constitucional no atual Estado Democrático de Direito."62

\section{COMO CITAR ESTE ARTIGO:}

MOREIRA, Rômulo de Andrade. O Supremo Tribunal Federal e a lei Maria da Penha - uma lamentável decisão. Revista Brasileira de Direito Processual Penal, Porto Alegre, vol. 2, n. 1, p. 145 - 184, 2016. http://dx.doi.org/10.22197/rbdpp.v2i1.20

62 Campos, Roberta Toledo. Aspectos constitucionais e penais significativos da Lei Maria da Penha. Disponível na internet www.ibccrim.org.br 04.09.2007. 